\title{
Kualitas Nutrisi Rumput Setaria spacellata yang Dipanen Berdasarkan Interval Pemotongan
}

\author{
Quality of the Nutrition of Setaria spacellata Grass Harvested Based on Cutting Intervals
}

\author{
P. R. Fitriana, Hidayat dan T. Akbarillah
}

Jurusan Peternakan, Fakultas Pertanian, Universitas Bengkulu.

Jl. W.R. Supratman Kandang Limun, Bengkulu 38371. Tel./Fax. +62-736-21290,

Koresponden e-mail : pujirahfiptr13@gmail.com

\begin{abstract}
This study aims to evaluate the nutrient content of the grasses of Setaria spacellata harvested based on different cutting intervals. This research was conducted in Laboratory of Livestock Department, Faculty of Agriculture, University of Bengkulu. The design used was Completely Randomized Design (RAL), with 3 treatments and 4 replications, ie P1 (cut 28 days), P2 (42 days), and P3 (56 days). The variables observed were water content, ash, coarse fat, coarse fiber, crude protein, and nitrogen extract (BETN). The results of the Setaria spacellata grass study showed that the shorter cut interval treatment resulted in ash content (P1 21.17\%, P2 17.97\%, and P3 $13.94 \%)$ and protein (P1 23.11\%, P2 23.44\%, and P3 20.31\%) higher than the longer cutting age (P <0.01). Organic materials ranged between $(78.83 \%-86.06 \%)$, crude fiber ranged between $(24.02 \%-30.41 \%)$, and BETN, ie P1 of $27.25 \%, \mathrm{P} 2$ of $26.00 \%$ and $\mathrm{P} 3$ of $31.17 \%$ for shorter cut off treatment was significantly lower than with longer cut length ( $\mathrm{P}<0.01$ ), whereas crude fats (P1 4.45\%, P2 3.90\%, and P3 4, 17\%) showed no significant effect $(\mathrm{P}>0.05)$. The production of Setaria spacellata grass nutrition shows that long cut intervals can increase the production of Setaria spacellata grass $(\mathrm{P}<0.01)$. This study can be concluded that the longer cutting interval increases the content of organic matter and crude fiber. The crude protein does not vary until the 42 day cut interval. The longer the cut interval increases the production of grass nutrients in spacellata.
\end{abstract}

Key words: cutting interval, proximate, Setaria spachaellata

\begin{abstract}
ABSTRAK
Penelitian ini bertujuan untuk mengevaluasi kandungan nutrisi rumput Setaria spacellata yang dipanen berdasarkan interval pemotongan yang berbeda. Penelitian ini dilaksanakan di Laboratorium Jurusan Peternakan, Fakultas Pertanian, Universitas Bengkulu. Rancangan yang digunakan adalah Rancangan Acak Lengkap (RAL), dengan 3 perlakuan dan 4 ulangan, yaitu P1 (umur potong 28 hari), P2 (42 hari), dan P3 (56 hari). Variabel yang diamati, yaitu kadar air, abu, lemak kasar, serat kasar, protein kasar, dan bahan ekstrak tanpa nitrogen (BETN). Hasil penelitian rumput Setaria spacellata menunjukkan bahwa perlakuan interval pemotongan yang lebih pendek menghasilkan kandungan abu (P1 21,17\%, P2 17,97\%, dan P3 13,94\%) dan protein (P1 23,11\%, P2 $23,44 \%$, dan $\mathrm{P} 320,31 \%)$ yang lebih tinggi dibandingkan dengan umur potong yang lebih panjang $(\mathrm{P}<0,01)$. Bahan organik berkisar antara $(78,83 \%-86,06 \%)$, serat kasar berkisar antara $(24,02 \%-30,41 \%)$, dan BETN, yaitu P1 sebesar 27,25\%, P2 sebesar 26,00\% dan P3 sebesar 31,17\% untuk perlakuan umur potong yang lebih pendek nyata lebih rendah dibandingkan dengan umur potong yang lebih panjang $(\mathrm{P}<0,01)$, sedangkan lemak kasar ( $\mathrm{P} 14,45 \%$, P2 3,90\%, dan P3 4,17\%) menunjukkan pengaruh yang tidak berpengaruh nyata ( $>00,05)$. Produksi nutrisi rumput Setaria spacellata menunjukkan bahwa interval pemotongan yang panjang dapat meningkatkan produksi nutrisi rumput Setaria spacellata $(\mathrm{P}<0,01)$. Penelitian ini dapat disimpulkan bahwa interval pemotongan yang semakin panjang meningkatkan kandungan bahan organik dan serat kasar. Protein kasar tidak berbeda sampai interval pemotongan 42 hari. Semakin panjang interval pemotongan meningkatkan produksi nutrisi rumput Setaria spacellata.
\end{abstract}

Kata kunci: interval pemotongan, proksimat, Setaria spachaellata

\section{PENDAHULUAN}

Hijauan pakan merupakan bahan
pakan utama yang digunakan untuk

memenuhi kebutuhan nutrisi atau zat makanan bagi ternak ruminansia agar dapat bertahan hidup, berproduksi, serta berkembang biak. Hijauan pakan bisa 
didapat dari berbagai macam tanaman pakan yang ada di Indonesia. Hijauan pakan ternakpada umumnya terdiri dari rumput dan leguminosa. Rumput yang ada di Indonesia banyak jenisnya dan nutrisinya pun berbeda-beda. Begitupun dengan interval pemotongan pada rumput, antara rumput muda dengan yang tua kualitas nutrisinya berbeda-beda. Sampai saat ini, sebagian besar pakan hijauan untuk ternak yang digunakan adalah rumput lokal atau disebut juga rumput alam.

Indonesia memiliki 2 musim, yaitu musim hujan dan musim kemarau yang datang setiap setengah tahun sekali. Pada musim kemarau ketersediaan akan hijauan sangat kurang, maka dari itu perlu penyediaan tanaman rumput pakan yang mempunyai kualitas, daya saing, toleransi, dan efisiensi yang lebih baik. Tidak seimbangnya produksi hijauan pada musim hujan dan musim kemarau menimbulkan kesulitan dalam penyediaan pakan hijauan secara baik (Sawen et al., 2003). Untuk mengatasi masalah tersebut maka perlu adanya upaya dengan cara mencari jenisjenis rumput unggul yang berproduksi tinggi dan tumbuh baik saat musim kemarau. Dalam hal ini dapat dilakukan dengan membudidayakan rumput Setaria misalnya, karena rumput ini memiliki penyebaran yang cukup luas. Rumput Setaria memiliki daya adaptasi yang tinggi terhadap jenis tanah dan iklim, sedikit tahan genangan, tahan lindungan, dan kekeringan. Rumput Setaria spacellata merupakan tanaman yang mempunyai kualitas yang baik sebagai hijauan pakan, hal ini dapat dilihat dari tingkat pertumbuhan, produktivitas hasil panen, maupun nutrisi yang terkandung didalamnya, sehingga rumput ini pun sangat disukai oleh ternak. Penanaman ataupun pembiakan rumput ini dapat dilakukan dengan pols (sobekan rumpun) dan dapat pula menggunakan biji (4-10 $\mathrm{kg} / \mathrm{ha}$ ) (Anonimous, 2003).

Pupuk merupakan suatu bahan yang mengandung unsur hara yang sangat penting bagi tanaman. Dalam hal ini pupuk feses kambing merupakan bahan yang mempunyai kandungan unsur hara lengkap dengan proporsi yang berbeda dan saling melengkapi satu sama lain.

Defoliasi atau pemotongan merupakan pengambilan bagian tanaman yang ada di atas permukaan tanah, baik oleh manusia maupun renggutan hewan itu sendiri di waktu ternak digembalakan (Susetyo dan Soewardi, 1969). Faktor yang perlu diperhatikan ketika akan melakukan pemotongan atau defoliasi antara lain frekuensi pemotongan, tinggi rendahnya batang tanaman yang ditinggalkan, pemotongan dengan paksa dan pengaturan dalam blok pemotongan (Sutopo, 1985).

Kualitas nutrisi bahan pakan merupakan faktor utama dalam memilih dan menggunakan bahan makanan tersebut sebagai sumber zat makanan untuk memenuhi kebutuhan hidup pokok dan produksinya, kualitas nutrisi bahan pakan terdiri atas komposisi nilai gizi, serat, energi, dan aplikasinya pada nilai palatabilitas dan daya cernanya (Sofyan $e t$ al., 2000). Secara umum kualitas hijauan didaerah tropis lebih rendah daripada di daerah subtropis karena kandungan $\mathrm{N}$ yang rendah dan kandungan serat kasar tinggi (Sumarsono et al., 2009).

Dalam hal ini, perlu dilakukan penelitian agar mengetahui kualitas nutrisi hijauan pada rumput Setaria spachaellata yang dipotong pada interval pemotongan yang berbeda. Penelitian ini bertujuan untuk mengevaluasi kandungan nutrisi rumput Setaria spachaellata (kadar air, 
abu, lemak kasar, serat kasar, dan protein kasar) yang dipanen berdasarkan interval pemotongan.

\section{MATERI DAN METODE}

Penelitian ini telah dilakukan pada bulan Februari sampai bulan Juli 2017 di lahan Produksi Hijauan Pakan dan Laboratorium Jurusan Peternakan Fakultas Pertanian Universitas Bengkulu. Alat yang digunakan pada penelitian ini adalah alat tulis, timbangan, arit, ember, kamera, koran, alat penjemur, gunting, plastik, dan peralatan yang digunakan di laboratorium. Bahan yang digunakan, yaitu rumput Setaria spachaellata yang sudah dipanen, pupuk kandang feses kambing, serta bahan-bahan yang digunakan di laboratorium.

Ada beberapa tahapan pada penelitian ini, diantaranya yaitu lahan yang digunakan pada penelitian ini adalah lahan dengan luas petakan $3 \mathrm{~m}$ x $5 \mathrm{~m}$ sebanyak 12 petak. Rumput Setaria sudah ditanam pada bulan Oktober 2016. Setiap petak percobaan ditanami 77 buah bibit rumput dengan jarak tanam $50 \mathrm{~cm} \mathrm{x} 50 \mathrm{~cm}$.

Melakukan pemupukan lanjutan setelah pemotongan pertama. Pupuk yang digunakan adalah pupuk kandang berupa feses kambing. Penggunaan pupuk feses kambing diberikan sesuai dengan kebutuhan, dosis yang diperlukan ialah 20 ton/ha. Untuk luas lahan $15 \mathrm{~m}^{2}$ dengan lubang tanam 77 buah, maka setiap lubang memerlukan pupuk feses kambing sebanyak 389,6 gram.

Melakukan pemotongan rumput saat rumput berumur 28 hari, 42 hari, dan 56 hari. Pemotongan dilakukan dengan memotong bagian arial, $5 \mathrm{~cm}$ dari permukaan tanah. Setelah melakukan pemotongan, mengambil sampel rumput
Setaria spacellata. Sampel diambil sebanyak 534 gram pada setiap kantong kertas, selanjutnya melakukan penjemuran sampel hingga beratnya konstan.

Selanjutnya melakukan penggilingan atau penghalusan pada sampel rumput untuk pengayakan dengan menggunakan saringan berdiameter $1 \mathrm{~mm}$. Selanjutnya mengambil sampel yang sudah diayak dengan saringan untuk dilakukan analisis kualitas nutrisi rumput Setaria spacellata.

Analisis proksimat meliputi kadar air, abu, protein kasar, lemak kasar, dan serat kasar (AOAC, 2005).

Penelitian ini menggunakan Rancangan Acak Lengkap (RAL), dengan 3 perlakuan dan 4 ulangan. Adapun perlakuannya adalah:

P1= Rumput Setaria spacellata dengan interval pemotongan 28 hari.

P2= Rumput Setaria spacellata dengan interval pemotongan 42 hari.

P3= Rumput Setaria spacellata dengan interval pemotongan 56 hari.

Variabel yang diamati dalam penelitian ini, yaitu kandungan nutrisi rumput Setaria dengan melakukan analisis proksimat (kadar air, bahan kering,kadar abu, bahan organik, kadar lemak, serat kasar, kadar protein, dan BETN).

Variabel pendukung yang diamati selama penelitian meliputi kandungan NPK tanah dengan menganalisis di laboratorium tanah BPTP Bengkulu serta iklim (curah hujan, temperatur udara, kelembaban udara, dan intensitas cahaya matahari) dengan meminta data dari BMKG Provinsi Bengkulu.

Data yang diperoleh dianalisis dengan sidik ragam (ANOVA). Apabila hasil analisis berpengaruh nyata $(\mathrm{P}<0,05)$ maka dilanjutkan dengan Uji Duncan's Multiple Range Test (DMRT). 
HASIL DAN PEMBAHASAN

\section{Kandungan Nutrisi Rumput Setaria spacellata atas Dasar Bahan Kering}

Rataan kandungan nutrisi rumput Setaria spacellata atas dasar bahan kering selama penelitian dapat dilihat pada Tabel 1 dibawah ini:

Tabel 1. Rataan kandungan nutrisi rumput Setaria spacellata atas dasar bahan

\begin{tabular}{lcccc}
\hline \multirow{2}{*}{ Variabel } & \multicolumn{3}{c}{ Perlakuan } & \multirow{2}{*}{ P } \\
\cline { 2 - 4 } & P1 & P2 & P3 & \\
\hline & $----1,-1,97^{\mathrm{b}} \pm 0,73$ & $13,94^{\mathrm{c}} \pm 1,16$ & 0,0000 \\
Abu & $21,17^{\mathrm{a}} \pm 0,38$ & $17,03^{\mathrm{b}} \pm 0,73$ & $86,06^{\mathrm{c}} \pm 1,16$ & 0,0000 \\
Bahan organik & $78,83^{\mathrm{a}} \pm 0,38$ & $3,90 \pm 0,44$ & $4,17 \pm 0,45$ & 0,2391 \\
Lemak kasar & $4,45 \pm 0,36$ & $28,69^{\mathrm{b}} \pm 0,83$ & $30,41^{\mathrm{c}} \pm 1,10$ & 0,0000 \\
Serat kasar & $24,02^{\mathrm{a}} \pm 0,61$ & $23,44^{\mathrm{a}} \pm 0,94$ & $20,31^{\mathrm{b}} \pm 1,04$ & 0,0035 \\
Protein kasar & $23,11^{\mathrm{a}} \pm 1,09$ & $26,00^{\mathrm{a}} \pm 0,59$ & $31,17^{\mathrm{b}} \pm 0,64$ & 0,0000 \\
BETN & $27,25^{\mathrm{a}} \pm 1,45$ &
\end{tabular}

Keterangan: $\mathrm{P} 1=$ umur 28 hari, $\mathrm{P} 2=$ Umur 42 hari, $\mathrm{P} 3=$ umur 56 hari. Superskrip pada baris yang sama

berpengaruh sangat nyata $(\mathrm{P}<0,01)$.

Hasil analisis ragam menunjukkan bahwa interval pemotongan berpengaruh sangat nyata $(\mathrm{P}<0,01)$ terhadap kandungan abu rumput Setaria spacellata. Berdasarkan uji lanjut kandungan abu P1 sebesar $21,17 \%$ sangat nyata lebih tinggi dibanding P2 dan P3, demikian dengan abu P2 sebesar $17,97 \%$ sangat nyata lebih tinggi dibandingkan dengan P3 sebesar 13,94\%. Hasil tersebut menunjukkan semakin panjang interval pemotongan rumput maka semakin menurun kandungan abunya. Hal tersebut sependapat dengan Hartadi et al. (2005), yang menyatakan bahwa serat kasar rumput Setaria yang tumbuh 15 sampai 28 hari mengandung abu sebesar $14,3 \%$, sedangkan rumput Setaria yang tumbuh 43 sampai 56 hari mengandung abu sebesar 11,1\%. Tingginya kadar abu pada rumput muda umur 28 hari karena bahan organik yang terbentuk lebih rendah karena terdapat lebih banyak sel yang aktif jika dibandingkan dengan rumput tua umur 42 hari dan 56 hari yang memiliki lebih banyak sel yang aktif membentuk bahan organik semakin tinggi.

Hasil analisis ragam menunjukkan bahwa interval pemotongan berpengaruh sangat nyata $(\mathrm{P}<0,01)$ terhadap kandungan bahan organik rumput Setaria spacellata. Berdasarkan uji lanjut P1 sebesar 78,83\% sangat nyata lebih rendah dibanding dengan P2 dan P3, demikian juga bahan organik P2 sebesar $82,03 \%$ sangat nyata lebih rendah dibanding dengan P3 86,06\%. Dari hasil tersebut berarti semakin panjang interval pemotongan rumput, maka semakin meningkat bahan organik yang dihasilkan oleh rumput Setaria spacellata. Menurut Kartasapoetra (1991), semakin panjang interval pemotongan tanaman maka daun akan melakukan proses fotosintesis yang semakin lama sehingga dapat meningkatkan produksi gula sederhana yang mengakibatkan kandungan bahan organik meningkat.

Hasil analisis ragam menunjukkan interval pemotongan berpengaruh tidak nyata $(\mathrm{P}>0,05)$ terhadap kandungan lemak kasar rumput Setaria spacellata. Kandungan lemak kasar antara P1, P2, dan P3 tidak berbeda nyata. Pada Tabel 1 . dapat terlihat bahwa interval pemotongan tidak/belum meningkatkan kandungan lemak kasar.

Hasil analisis ragam menunjukkan interval pemotongan berpengaruh sangat 
nyata $(\mathrm{P}<0,01)$ terhadap kandungan serat kasar rumput Setaria spacellata. Hasil uji lanjut kandungan serat kasar P1 sebesar $24,02 \%$ sangat nyata lebih rendah dibanding dengan P2 dan P3, demikian juga dengan serat kasar P2 sebesar 28,69\% lebih rendah dibanding dengan P3 yaitu $30,41 \%$. Hal ini disebabkan karena semakin panjang interval pemotongan rumput maka semakin meningkat kandungan serat kasar yang dimiliki oleh rumput Setaria spacellata. Seperti yang diungkapkan oleh Tillman et al. (1998) bahwa kadar serat kasar hijauan akan meningkat dengan semakin tuanya umur tanaman. Menurut Hartadi et al. (2005), serat kasar rumput Setaria yang tumbuh antara 15 sampai 28 hari mengandung serat kasar sebesar 25,5\% dan yang tumbuh antara 43 sampai 56 hari mengandung serat kasar sebesar $31,7 \%$. Hal ini tidak berbeda jauh dengan kandungan serat kasar yang telah dilakukan dalam penelitian ini. Dengan kandungan serat kasar pada P1, P2, dan P3 menunjukkan hasil yang baik, karena ternak kambing masih mau mengkonsumsi rumput tersebut sampai umur 56 hari, namun yang paling di sukai adalah rumput P1 dan P2 karena kandungan serat kasarnya masih rendah dibandingkan dengan P3.

Hasil analisis ragam menunjukkan bahwa interval pemotongan berpengaruh sangat nyata $(\mathrm{P}<0,01)$ terhadap kandungan protein kasar rumput Setaria spacellata. Hasil uji lanjut protein kasar P1 sebesar $23,11 \%$ tidak berbeda nyata dengan P2 yaitu sebesar 23,44\%, tetapi P1 dan P2 berbeda sangat nyata dengan P3 sebesar 20,31\%. Dari data tersebut sependapat dengan Hartadi et al. (2005) bahwa rumput Setaria yang tumbuh 15 sampai 28 hari mengandung protein kasar sebesar 14,3\% dan rumput yang tumbuh 43 sampai 56 hari mengandung protein kasar sebesar $9,5 \%$. Hal ini menunjukkan bahwa pada interval pemotongan rumput 56 hari berada pada fase reproduktif sehingga terdapat kandungan serat kasar yang lebih tinggi, dan menurunkan kandungan protein kasar. Interval pemotongan P1 umur 28 hari dan P2 umur 42 hari kandungan serat kasarnya masih rendah karena masih berada pada fase vegetatif. Seperti yang diungkapkan oleh Mansyur et al. (2005), jika interval pemotongan diperpanjang akan terjadi penurunan kandungan proteinkasar. Tingginya kadar protein kasar pada rumput muda disebabkan karena fungsi dari protein yang digunakan sebagai pembentuk sel, jaringan, dan organ tanaman serta berfungsi sebagai bahan sintetis klorofil, enzim, dan asam amino yang lebih banyak terjadi pada tanaman muda dibandingkan dengan tanaman tua (Salisbury dan Ross, 1995). Dalam hal ini, pengamatan empiris menunjukkan bahwa rumput dengan masing-masing perlakuan dapat di terima oleh ternak kambing, tetapi rumput dengan umur 28 hari dan umur 42 hari nilai palatabilitasnya lebih tinggi di bandingkan dengan umur 56 hari. Ternak kambing sangat menyukai rumput $\mathrm{P} 1$ dan $\mathrm{P} 2$, hal ini dikarenakan rumput tersebut memiliki protein kasar yang lebih tinggi dan serat kasar lebih rendah dibandingkan dengan P3 yang sudah mulai banyak mengandung serat kasar.

Berdasarkan analisis ragam menunjukkan interval pemotongan berpengaruh sangat nyata $(\mathrm{P}<0,01)$ terhadap bahan ekstrak tanpa nitrogen (BETN) rumput Setaria spacellata. Hasil uji lanjut pada perlakuan P1 sebesar $27,25 \%$ tidak berbeda nyata dengan P2 sebesar 26,00\%, tetapi P1 dan P2 berbeda sangat nyata dengan P3 sebesar 31,17\%. Perlakuan P3 memiliki kandungan BETN 
tertinggi dibandingkan dengan $\mathrm{P} 1$ dan $\mathrm{P} 2$. Menurut Hartadi et al. (2005) menyatakan bahwa rumput Setaria yang tumbuh 15 sampai 28 hari mengandung BETN sebesar $42,9 \%$ dan rumput Setaria yang tumbuh 43 sampai 56 hari mengandung BETN sebesar 45,2\%. Hal tersebut menunjukkan bahwa pada interval pemotongan rumput yang semakin panjang meningkatkan kandungan BETN, tetapi tidak pada perlakuan dengan interval pemotongan 42 hari yang mengalami penurunan kandungan BETN. Kandungan BETN ini sangat tergantung pada komponen lainnya, seperti abu, protein kasar, serat kasar, dan lemak kasar. Sutardi (2006) menambahkan bahwa kandungan BETN suatu bahan pakan sangat tergantung oleh komponen lainnya, seperti air, abu, protein kasar, lemak kasar, dan serat kasar dikurangi dari, perbedaan itu disebut bahan ekstrak tanpa nitrogen
(BETN). Rendahnya kadar BETN pada rumput yang berumur muda karena kadar protein kasar pada rumput yang berumur muda lebih tinggi dari rumput yang berumur lebih tua. Tingginya penjumlahan kadar protein kasar, abu, lemak kasar, dan serat kasar pada rumput berumur muda akan diikuti oleh rendahnya kandungan BETN pada rumput muda. Hal ini dikarenakan kadar nitrogen yang ada seluruhnya terhitung sebagai protein kasar sehingga tingginya kadar protein kasar akan menurunkan kadar BETN (Devenda, 1977).

\section{Produksi Nutrisi Hijauan Rumput Setaria spacellata}

Hasil produksi nutrisi rumput Setaria spacellata yang dipanen berdasarkan interval pemotongan dapat dilihat pada Tabel 2 dibawah ini:

Tabel 2. Rataan produksi nutrisi rumput Setaria spacellata

\begin{tabular}{|c|c|c|c|c|}
\hline \multirow[b]{2}{*}{ Variabel } & \multicolumn{3}{|c|}{ Perlakuan } & \multirow[b]{2}{*}{$P$} \\
\hline & $\mathrm{P} 1$ & $\mathrm{P} 2$ & P3 & \\
\hline & & - gram/petak -- & & \\
\hline Bahan kering & $2018,91^{\mathrm{a}} \pm 589,94$ & $5147,42^{\mathrm{b}} \pm 588,55$ & $9133,95^{\mathrm{c}} \pm 954,75$ & 0,0000 \\
\hline Abu & $427,14^{\mathrm{a}} \pm 124,29$ & $927,81^{b} \pm 139,80$ & $1275,85^{\mathrm{c}} \pm 190,14$ & 0,0009 \\
\hline Bahan organik & $1591,76^{\mathrm{a}} \pm 465,94$ & $4219,60^{\mathrm{b}} \pm 449,41$ & $7858,10^{c} \pm 801,65$ & 0,0009 \\
\hline Lemak kasar & $90,72^{\mathrm{a}} \pm 30,95$ & $201,83^{\mathrm{b}} \pm 40,07$ & $379,67^{\mathrm{c}} \pm 46,23$ & 0,0000 \\
\hline Serat kasar & $484,12^{\mathrm{a}} \pm 140,54$ & $1475,36^{\mathrm{b}} \pm 159,13$ & $2773,19^{c} \pm 244,50$ & 0,0000 \\
\hline Protein kasar & $462,77^{\mathrm{a}} \pm 120,92$ & $1206,54^{b} \pm 145,57$ & $1859,76^{\mathrm{c}} \pm 268,60$ & 0,0000 \\
\hline BETN & $554,15^{\mathrm{a}} \pm 176,56$ & $1335,88^{b} \pm 123,88$ & $2845,48^{c} \pm 285,10$ & 0,0000 \\
\hline
\end{tabular}

Keterangan: $\mathrm{P} 1=$ rumput umur 28 hari, $\mathrm{P} 2=$ rumput umur 42 hari, $\mathrm{P} 3=$ rumput umur 56 hari.

Superskrip berbeda pada baris yang sama menunjukkan berpengaruh sangat nyata $(\mathrm{P}<0,01)$.

Hasil analisis ragam menunjukkan bahwa interval pemotongan berpengaruh sangat nyata $(\mathrm{P}<0,01)$ terhadap produksi bahan kering, abu, bahan organik, lemak kasar, serat kasar, protein kasar, dan BETN rumput Setaria spacellata. Berdasarkan hasil uji lanjut menunjukkan produksi bahan kering rumput Setaria perlakuan P1 sebesar 2.018,91 gram/petak sangat nyata lebih rendah dibandingkan dengan $\mathrm{P} 2$ dan P3, demikian juga dengan perlakuan P2 sebesar 5.147,42 gram/petak sangat nyata lebih rendah dibandingkan dengan P3 yaitu sebesar 9.133,95 gram/petak. Pada Tabel 2. terlihat bahwa rataan tertinggi produksi bahan kering terdapat pada perlakuan P3, kemudian diikuti oleh P2 dan P1. Dalam hal ini rumput Setaria dengan interval pemotongan yang semakin panjang dapat meningkatkan produksi bahan kering. Menurut Beever et al. (2000) dalam Savitri et al. (2012) bahwa semakin tua umur 
tanaman maka kandungan airnya lebih sedikit dan proporsi dinding sel lebih tinggi dibandingkan dengan isi sel. Menurut pendapat Rochiman et al. (2000) yang menyebutkan bahwa interval pemotongan yang panjang memberikan produksi bahan kering lebih tinggi daripada interval pemotongan yang pendek. Berdasarkan hasil uji lanjut menunjukkan produksi abu perlakuan P1 sebesar 427,14 gram/petak sangat nyata lebih rendah dibandingkan dengan P2 dan P3, produksi abu P2 sebesar 927,81 gram/petak sangat nyata lebih rendah dibandingkan dengan P3 sebesar 1.275,85 gram/petak. Dalam hal ini diketahui bahwa semakin panjang interval pemotongan, maka semakin tinggi produksi abu yang terkandung, walaupun menurunkan kualitas abu.

Produksi bahan organik yang menunjukkan pengaruh sangat nyata berdasarkan hasil uji lanjut produksi bahan organik perlakuan P1 sebesar 1.591,76 gram/petak sangat nyata lebih rendah dibandingkan dengan P2 dan P3, begitu juga dengan produksi bahan organik P2 sebesar 4.219,60 gram/petak sangat nyata lebih rendah dibandingkan dengan P3 sebesar 7.858,10 gram/petak. Data tersebut menunjukkan semakin panjang interval pemotongan rumput, maka produksi bahan organik yang dimiliki semakin meningkat. Interval pemotongan yang semakin panjang menyebabkan semakin lama proses fotosintesis sehingga meningkatkan kualitas bahan organik. Kandungan bahan organik dan produksi bahan kering yang terus meningkat seiring dengan meningkatnya interval pemotongan juga menghasilkan peningkatan produksi bahan organik. Dalam hal ini rumput Setaria spacellata dengan interval pemotongan yang semakin panjang mulai dari umur 28 hari, 42 hari, dan 56 hari meningkatkan produksi bahan organik.

Hasil uji lanjut menunjukkan bahwa produksi lemak kasar yang dihasilkan perlakuan P1 sebesar 90,72 gram/petak sangat nyata lebih rendah dibandingkan dengan P2 dan P3, demikian juga dengan produksi lemak kasar P2 sebesar 201,83 gram/petak sangat nyata lebih rendah dibandingkan dengan P3 yaitu sebesar 379,67 gram/petak. Tabel 2. menunjukkan bahwa produksi lemak kasar rumput Setaria spacellata tertinggi ditunjukkan pada perlakuan P3. Interval pemotongan yang semakin panjang dapat meningkatkan produksi lemak kasar. Dalam hal ini, walaupun kandungan nutrisi lemak kasar tidak berpengaruh nyata $(\mathrm{P}>0,05)$, namun pada produksi lemak kasar berpengaruh sangat nyata $(\mathrm{P}<0,01)$ dan menaikkan produksi lemak kasar. Hal ini disebabkan karena produksi bahan kering meningkat dengan meningkatnya interval pemotongan.

Berdasarkan hasil uji lanjut menunjukkan bahwa produksi serat kasar perlakuan P1 sebesar 484,12 gram/petak sangat nyata lebih rendah dibandingkan dengan P2 dan P3, demikian pula produksi serat kasar P2 sebesar 1.475,36 gram/petak sangat nyata lebih rendah dibandingkan dengan P3 sebesar 2.773,19 gram/petak. Peningkatan produksi serat kasar disebabkan karena terjadinya proses lignifikasi yang semakin tinggi seiring dengan lamanya interval pemotongan sehingga kandungan nutrisi pada serat kasar dan produksi serat kasar juga meningkat. Tinggi rendahnya produksi serat kasar dipengaruhi oleh interval pemotongan. Seperti menurut Erwanto (1984) dalam Fachrudin et al. (2012), mengatakan bahwa semakin tua umur 
tanaman maka semakin meningkat kandungan serat kasarnya.

Berdasarkan hasil uji lanjut menunjukkan bahwa produksi protein kasar pada perlakuan P1 sebesar 462,77 gram/petak sangat nyata lebih rendah dibandingkan P2 dan P3, demikian juga dengan produksi protein kasar P2 sebesar 1.206,54 gram/petak sangat nyata lebih rendah dibandingkan dengan P3 yaitu sebesar 1.859,76 gram/petak. Dengan kandungan nutrisi protein kasar dan produksi bahan kering yang berbeda, produksi protein kasar berbeda sangat nyata. Dari hasil tersebut menjelaskan bahwa produksi protein kasar dari setiap perlakuan memperlihatkan kenaikan produksi protein kasar seiring dengan panjangnya interval pemotongan. Produksi protein kasar sangat berkaitan dengan produksi daun yang semakin banyak sehingga semakin banyak produksi protein kasar. Seperti yang dikatakan oleh Suryana dan Lugiyo (2006) dalam Savitri et al. (2013) menyatakan bahwa protein tanaman berhubungan erat dengan aktivitas jaringan, sehingga daun mengandung lebih banyak protein dibandingkan dengan batang. Tidak hanya umur yang mempengaruhi, tetapi juga didukung oleh kandungan hara yang ada pada tanah dan pada pupuk kandang feses kambing. Menurut Minson (1990), Kaunang (2005) dalam Marliani (2010) menyatakan kandungan dan komposisi protein kasar dalam hijauan dapat dipengaruhi oleh ketersediaan nitrogen dalam tanah, akibatnya bisa menghambat proses sintesis protein kasar pada tanaman.

Berdasarkan hasil uji lanjut menunjukkan bahwa produksi BETN pada perlakuan P1 sebesar 554,15 gram/petak sangat nyata lebih rendah dibandingkan dengan P2 dan P3, demikian juga dengan produksi BETN P2 sebesar 1.335,88 gram/petak sangat nyata lebih rendah dibandingkan dengan P3 sebesar 2.845,48 gram/petak. Dari hasil tersebut terlihat bahwa semakin panang interval pemotongan rumput, maka semakin tinggi produksi BETN rumput Setaria, hal ini seiring dengan kandungan nutrisi pada BETN yang semakin tinggi dengan interval pemotongan yang panjang. Tinggi rendahnya produksi BETN juga dapat dipengaruhi oleh produksi protein kasar pada rumput. Menurut Devenda (1977), bahwa kadar nitrogen yang ada seluruhnya terhitung sebagai protein kasar sehingga tingginya kadar protein kasar akan menurunkan kadar BETN.

\section{KESIMPULAN}

Interval pemotongan rumput Setaria spacellata dengan interval yang semakin panjang meningkatkan kandungan bahan organik dan serat kasar. Protein kasar tidak berbeda sampai interval pemotongan 42 hari. Dengan interval pemotongan 28 - 56 hari kualitasnya sudah baik dan masih di terima oleh ternak kambing, tetapi yang paling disukai adalah interval pemotongan 28 dan 42 hari. Semakin panjang interval pemotongan meningkatkan produksi nutrisi bahan kering, abu, lemak kasar, serat kasar, protein kasar, dan BETN.

\section{DAFTAR PUSTAKA}

Anonimus. 2003. Petunjuk budidaya hijauan makanan ternak. Balai Pembibitan Ternak.

Amalia, L., L. Aboenawan, E. B. Laconi, N. Ramli, M. Ridla dan A. D. Lubis. 2000. Diktat pengetahuan bahan makanan ternak. Laboratorium Ilmu dan Teknologi Pakan Fakultas Peternakan IPB. Bogor. 
AOAC, 2005. Official Methods of Analysis. Association of Official Analytical Chemists. Benjamin Franklin Station, Washington.

Devenda.1977. Cassava as a Feed Source for Ruminant. In: Cassava as Animal Feed. (Eds. Nestel, B and Graham, M). Procceding of Workshop. University of Guelph.Ottawa.

Fachrudin, R., F. Fathul. dan Liman. 2012. Evaluasi kandungan zat-zat makanan Kambing (Salvina molesta) di Waduk Batu Tegi Kecamatan Air Naningan Kabupaten Tanggamus. Jurnal Ilmiah Peternakan Terpadu. $1(1): 1-4$.

Hartadi, H., S. Reksohadiprodjo, dan A. D. Tillman. 2005. Tabel komposisi pakan untuk Indonesia. Gadjah Mada University Press. Yogyakarta.

Kartasapoetra, A. G. 1991. Pengantar anatomi tumbuh-tumbuhan. Rineka Cipta. Jakarta.

Marliani. 2010. Produksi dan kandungan gizi rumput Setaria (Setaria Sphacelata) pada pemotongan pertama yang ditanam dengan jenis pupuk kandang berbeda. Skripsi. Universitas Islam Negeri Sultan Syarif Kasim. Riau.

Mansyur, H. Djuned, T. Dhalika, S. Hardjosoewignyo, dan L. Abdullah. 2005. Pengaruh interval pemotongan dan inveksi gulma Chromolaena odorata terhadap produksi dan kualitas rumput Brachiaria humidicola. Media Peternakan. 28(2): 77-86.
Rochiman, K., S. Harjosoewignyo, dan A. Surkati. 2000. Pengaruh pupuk kandang, urea, dan interval pemotongan terhadap produksi serta ketahanan Stylosanthes guyanensis. Buletin Agronomi. XIV(2).

Salisbury, F. B dan C. W. Ross. 1995. Fisiologi Tumbuhan, Jilid 2. Institut Teknologi Bandung. Bandung.

Savitri, M. V., H. Sudarwati, dan Hermanto. 2013. Pengaruh umur pemotongan terhadap produktivitas gamal (Gliricidia sepium). Jurnal Ilmu-Ilmu Peternakan. 23(2): 25-35.

Sawen, D., O.Yoku, dan M. Junaidi. 2003. Kualitas silase rumput Irian (Sorghum Sp) dengan perlakuan penambahan dedak padi pada berbagai tingkat produksi bahan kering. Fakultas Peternakan Perikanan dan Ilmu Kelautan Universitas Negeri Papua, Manokwari, Papua.

Sofyan, L. A., L. Aboenawan, E. B. Laconi, A. Djamil, N. Ramli, M. Ridla, dan A.D. Lubis. 2000. Pengetahuan bahan makanan ternak. Lab. Ilmu dan Teknologi Pakan. Fakultas Peternakan IPB. Bogor.

Sumarsono, S., D. W. Anwar, dan S. Budiyanto. 2009. Penerapan Pupuk Organik untuk Perbaikan Penampilan dan Produksi Hijuan Rumput Gajah pada Tanah Masam. Seminar Nasional Kebangkitan Peternakan Semarang, Fakultas Peternakan, Univesitas Diponogoro, Semarang.

Susetyo, Kismono dan Soewardi. 1969. Hijauan makanan ternak. Direktorat Peternakan Rakyat. Direktorat 
e-ISSN 2528-7109

p-ISSN 1978-3000

Jenderal Peternakan, Departemen Pertanian, Jakarta.

Sutardi, T. 2006. Landasan Ilmu Nutrisi Jilid 1. Departemen Ilmu Makanan Ternak. Bogor: Fakultas Peternakan IPB.
Sutopo, L. 1985. Teknologi Benih. CV. Rajawali, Jakarta.

Tillman, A. D., H. Hartadi, R. Soedomo, P. Soeharto, dan L. Soekanto. 1998. Ilmu Makanan Ternak Dasar. Gadjah Mada University. 